\title{
河川の移動床歪模型相似則とその有効性
}

\section{A STUDY ON THE SIMILARITY LAWS OF DISTORTED MODEL WITH A MOVABLE BED AND ITS VALIDITY}

\author{
魏 炳乾 ${ }^{1} \cdot$ 内島邦秀 $^{2}$. 早川 博 ${ }^{3}$. 仨出康郎 ${ }^{4}$ \\ WEI BingQian, Kunihide UCHIJIMA, Hiroshi HAYAKAWA and Yasuro IDE \\ ${ }^{1}$ 学生会員 修 (工) 北見工業大学大学院工学研究科システム工学専攻 (T090-8507 北海道北見市公園町 165 番地) \\ ${ }^{2}$ 正会員 博 (工） 北見工業大学助教授 工学部土木開発工学科（T090-8507 北海道北見市公園町 165 番地） \\ ${ }^{3}$ 正会員 博 (工）北見工業大学助手 工学部土木開発工学科（广090-8507 北海道北見市公園町 165 番地） \\ ${ }^{4}$ 正会員 工修 北海道開発局開発土木研究所河川研究室長（T062-8602 札幌市豊平区平岸 1 条 3 丁目）
}

\begin{abstract}
The theoretical backing of the similarity laws for distorted model with a movable bed obtained from dual dimensionless parameters of the bed-form classification diagram is given by solving the equations of similarity conditions which is obtained from 1-dimensional equation of motion, continuity equation, bed deformation equation and the formula of bed load transport. Secondly, by conducting distorted model experiments, which the experimental conditions are determined according to the similarity laws, the validity of the similarity laws is confirmed by comparing the bed form of distorted model experiment with that of undistorted model experiments performed by Hokkaido Development Bureau.
\end{abstract}

Key words : Similarity law, distorted model, light weight bed material, alternate bars, bars height.

\section{1.はじめに}

移動床歪模型相似則に関しては, Einstein·Chien ${ }^{1)}$ と Yalin²の研究があるが,これらの相似則にはそれぞれ制約 がある. Einstein·Chien の相似則は土砂初期運動(限界掃 流力)の相似条件を相似基準として用いているため, 流砂 量の多い流れに適用できない. Yalinは, 砂粒 Reynolds 数, 無次元掃流力, Froude 数と表面摩擦を相似基準として移 動床歪模型相似則を提案しているが，模型河床材料は砂 より比重の小さい材料に制約され，砂を用いるとすれば その大きさが実物大となり縮尺模型実験はできない.

以上のような制約がなく利用し易い相似則として, 内 島ら ${ }^{3)}$ ４) は砂州形成領域区分図両軸の無次元パラメータ 一を模型と原型で一致させることによって導出される移 動床歪模型の相似則を提案し, いくつかの急流河川を対 象として河床形の再現実験を行い，良好な検証結果を得 ている5), 6.

本研究では，まず，鮏川 万らの砂州形成領域区分図の 無次元パラメーターに基づく歪模型相似則（以下，領域区 分図に基づく相似則と呼ぶりに限定し，その相似則の導出
を理論的に補完するため, 一次元の流れの運動方程式と 連続式及び流砂の連続式と流砂量式より相似則を導き， 領域区分図に基づく相似則と比較検討する. 続いて, 2 種類の河床材料を用いて歪模型実験を行い, 原型河床形 状の再現性について検討し, 移動床歪模型相似則の有効 性を検証する. さらに蛇曲程度の河道湾曲の影響による 河床形の相似性について考察する.

\section{2. 一次元の基本方程式に基づいた歪模型の相似則}

一次元の流れの運動方程式と連続式は式(1)，（2）であ り, 流砂の連続式は式(3)である. 掃流砂量式は, 式(4) の Brown 型を用いる.

$$
\begin{gathered}
-I+\frac{\partial h}{\partial x}+\frac{1}{g} \frac{\partial U}{\partial t}+\frac{U}{g} \frac{\partial U}{\partial x}+\frac{U^{2} N^{2}}{h^{4 / 3}}=0 \\
\frac{\partial h}{\partial t}+\frac{1}{B} \frac{\partial Q}{\partial x}=0 \\
\frac{\partial z}{\partial t_{s}}+\frac{1}{1-\lambda} \frac{\partial q_{s}}{\partial x}=0
\end{gathered}
$$




$$
\frac{q_{s}}{u_{*} d}=k\left(\tau_{*}-\tau_{*_{c}}\right)^{b}
$$

ここで, $h$ : 水深, $B:$ 川幅, $Q:$ 流量, $U:$ 平均流速, $I$ : 河床勾配, $u_{*}$ : 摩擦速度 $\left(=\sqrt{g h I_{e}}, I_{e}\right.$ : エネルギ一勾配 ,

$t:$ 時間, $N$ : 粗度係数, $g$ : 重力加速度, $x$ : 流れ方向に とつた長さ, $z$ : 河床高, $d:$ 河床材料の平均粒径, $t_{s}$ : 河床変形の時間, $\lambda$ : 河床砂の空隙率, $\tau_{*}$ : 無次元掃流 力, $\tau_{*_{c}}$ : 無次元限界掃流力, $q_{s}$ : 単位幅, 単位時間当 たりの流砂量, $k$ と $b$ : 定数である.

水理量の(原型值/模型值)を縮尺比, その逆数を縮尺と 定義する. 以後，原型值，模型值及び縮尺比をそれぞれ 添字 $p, m, r$ で表す. 式(1)，(2)，(3)，(4)が原型と模 型でともに成立することによって, 縮尺比の定義より, 式(1)から次の式(5)が得られ,

$$
I_{r}=\frac{h_{r}}{x_{r}}=\frac{U_{r}}{g_{r} t_{r}}=\frac{U_{r}^{2}}{g_{r} x_{r}}=\frac{U_{r}^{2} N_{r}^{2}}{h_{r}^{4 / 3}}
$$

式(2)および式(3)から，それぞれ式(6)，(7)が得られる.

$$
\begin{gathered}
\frac{h_{r}}{t_{r}}=\frac{Q_{r}}{B_{r} x_{r}} \\
\frac{z_{r}}{t_{s_{r}}}=\frac{q_{s_{r}}}{(1-\lambda)_{r} x_{r}}
\end{gathered}
$$

また, 式(4)から, 次の式(8)を得る.

$$
\frac{q_{s_{r}}}{u_{*_{r}} d_{r}}=k_{r}\left(\tau_{*}-\tau_{*_{c}}\right)_{r}^{b}
$$

次に, 水平方向縮尺比を $B_{r}\left(=x_{r}\right)$, 鈶直方向縮尺比を $Y_{r}\left(=h_{r}=z_{r}\right)$ として, 歪比 $n$ を $n=B_{r} / Y_{r}$ と定義する. これによ れば, 水路勾配の縮尺比 $I_{r}$ は $I_{r}=n^{-1}$ となる. したがって, $g_{r}=1$ であるから, 式(5)から次の相似条件式が求められる.

$$
\begin{aligned}
\frac{n h_{r}}{B_{r}} & =1 & \text { (9) } & \frac{n U_{r}}{t_{r}}=1 \\
\frac{n U_{r}^{2}}{B_{r}} & =1 & \text { (11) } & \frac{n U_{r}^{2} N_{r}^{2}}{h_{r}^{4 / 3}}=1
\end{aligned}
$$

$Q_{r}=B_{r} h_{r} U_{r}$ であるから, 式(6)から相似条件式(13)が求め

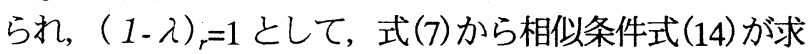
められる.

$$
\frac{U_{r} t_{r}}{B_{r}}=1 \quad \text { (13) } \quad \frac{q_{s_{r}} t_{s_{r}}}{B_{r} h_{r}}=1
$$

さらに, $k_{r}=1$ とし, 流砂量が相似となるためには, 式 （8）より $\left(\tau_{*}-\tau_{*}\right)_{r}=1$ となる必要がある. 河床材料の 移動限界付近の流砂相似条件は $\left(\tau_{*} / \tau_{* c}\right)_{r}=1$ であり ${ }^{8)}$, こ の条件を用いても $\left(\tau_{*}-\tau_{*}\right)_{r}=\tau_{*}$ となって, 結局 $\tau_{*}=$ $\tau_{*_{c}}=1$ が必要条件となる. したがって, 流砂量の相似条

\section{表-1 移動床歪模型の相似則}

\begin{tabular}{|l|l|l|c|}
\hline $\begin{array}{c}\text { 基本方程式による } \\
\text { 相似則 }\end{array}$ & $\begin{array}{c}\text { 式 } \\
\text { 番号 }\end{array}$ & \multicolumn{1}{|c|}{ 領域区分図に基づく相 } & $\begin{array}{c}\text { 式 } \\
\text { 似則 }\end{array}$ \\
\hline$d_{r}=s_{r}^{-1} n^{-2} B_{r}$ & $(18)$ & $d_{r}=s_{r}^{-1} n^{-2} B_{r}$ & $(27)$ \\
\hline$h_{r}=n^{-1} B_{r}$ & $(19)$ & $h_{r}=n^{-1} B_{r}$ & $(28)$ \\
\hline$N_{r}=n^{-2 / 3} B_{r}^{1 / 6}$ & $(20)$ & $N_{r}=s_{r}^{-1 / 6} n^{-1 / 3} B_{r}^{1 / 6}$ & $(29)$ \\
\hline$q_{s_{r}}=s_{r}^{-1} n^{-3} B_{r}^{3 / 2}$ & $(21)$ & $q_{s_{r}}=s_{r}^{-1} n^{-3} B_{r}^{3 / 2}$ & $(30)$ \\
\hline$t_{r}=n^{1 / 2} B_{r}^{1 / 2}$ & $(22)$ & $t_{r}=s_{r}^{-1 / 6} n^{5 / 6} B_{r}^{1 / 2}$ & $(31)$ \\
\hline$t_{s_{r}}=s_{r} n^{2} B_{r}^{1 / 2}$ & $(23)$ & $t_{s_{r}}=s_{r} n^{2} B_{r}^{1 / 2}$ & $(32)$ \\
\hline$U_{r}=n^{-1 / 2} B_{r}^{1 / 2}$ & $(24)$ & $U_{r}=s_{r}^{1 / 6} n^{-5 / 6} B_{r}^{1 / 2}$ & $(33)$ \\
\hline$Q_{r}=n^{-3 / 2} B_{r}^{5 / 2}$ & $(25)$ & $Q_{r}=s_{r}^{1 / 6} n^{-11 / 6} B_{r}^{5 / 2}$ & $(34)$ \\
\hline$F r_{r}=1$ & $(26)$ & $F r_{r}=s_{r}^{1 / 6} n^{-1 / 3}$ & $(35)$ \\
\hline
\end{tabular}

件は, $I_{e r}=I_{r}$ であるから式(8)より式(15)になる. 当然，無 次元掃流力 $\tau$. $=h I / s d(s$ : 河床材料の水中比重) を考慮して, 流砂相似条件式(16)を付加する.

$$
\frac{q_{s_{r}} n^{1 / 2}}{d_{r} h_{r}^{1 / 2}}=1 \quad \text { (15) } \quad \frac{n^{-1} h_{r}}{s_{r} d_{r}}=1
$$

以上の相似条件式(9)〜（16）において, 式(13)の条件下 では式(10) と(11) は同等であり，いずれか一方を採用す ればよい。ここでは, 式(10)を用い，相似条件式をまと めて示すと, 次の (17) 式となる.

$$
\begin{aligned}
n h_{r} & =B_{r} \\
n U_{r} & =t_{r} \\
U_{r} t_{r} & =B_{r} \\
n U_{r}^{2} N_{r}^{2} & =h_{r}^{4 / 3} \\
q_{s_{r}} t_{s_{r}} & =B_{r} h_{r} \\
n^{1 / 2} q_{s_{r}} & =d_{r} h_{r}^{1 / 2} \\
n^{-1} h_{r} & =s_{r} d_{r}
\end{aligned}
$$

相似条件式(17)において，7個の式中に 10 個の未知数 が存在するので, その内の 3 個の物理量を独立に選択す れば他の水理量の縮尺比を導ける．ここでは，模型を実 験室に収めるための水平縮尺比 $B_{r}$ と $I_{r}$, 即ち, 歪比 $n$ 及 び $s_{r}$ をあらかじめ選ぶことにすると,式(17)から表一1に 示す相似則 (18) (24)が求められる. 流量 $(Q)$ と Froude 数 $(F r)$ の相似則はそれぞれの定義より式 (25)、(26) とな る. また, 表-1には, 鮮川らの砂州形成領域区分図の無 次元パラメーターから求まる相似則も併記した. この誘 導の詳細は参考文献 3) で述べているので, 以下に留意点 のみ概説する. 領域区分図両軸の無次元パラメーターが 原型と模型て等しいとする相似条件 $\left(u_{*} / u_{*}\right)_{r}=1$ (即ち, $\tau$ $\left.{ }_{r}=1\right)$ と $(B \cdot I / h)_{r}=1$ より求まった相似則（27）、（28）に基づ いて, Manning-Strickler 型抵抗則 $\left(U / u_{*}=6.0(h / d)^{1 / 6}\right)$ と式 (7) および式(8) を独立に用いて求まる相似則が式 (29) (35)である. 
二つの相似則を比べると, $d_{r}, h_{r}, q_{s}, t_{s}$ の相似式は同 じであり，領域区分図の無次元パラメーターに基づく相 似条件には，流れと流砂の相似が含んでいると解釈でき る. また，他の相似式も同型であることから領域区分図 に基づく相似則の妥当性が理論的に説明できたと言える.

式(24) と式(33)が違うのは, 式(33)は砂州上の流れの 抵抗則之して Manning-Strickler 型公式を用いて導かれた もので, 摩擦抵抗と形状抵抗を含むが, 式(24) は摩擦抵 抗のみと考えられる. したがって, 抵抗に関与する式(20), （24）によって抵抗を相似にすることは難しく, 式(26)の Froude 相似も成り立たなくなる. 領域区分図に基づく相 似則は，その導出過程で原型の河床形態に応じた抵抗則 を選択することができ，汎用性があると考えられる.

そこで, 以下では歪模型相似則として領域区分図に基 づく相似則を用い，歪模型実駼結果によってその有効性 を検討する。

\section{3．歪模型相似則の有効性についての実験的檢証}

模型実験の対象河川は石狩川水系忠別川である. 忠別 川の河床形状は, 中・下流部で複列砂州を形成しており, 横断形状は四状で, 洪水の度に局所洗据や側岸侵食を起 こし易い河川である.このため, 平成 7 年度に北海道開 発局で, 中規模以上の洪水に対する複列砂州の単列化を 目的として現況河川の堤防法線間のほぼ中央位置に幅 $100 \mathrm{~m}$ の低水路を試みに設けた河道改修案を提案し, 縮尺 1/50 の大型無歪模型実験（河床材料 : 砂) を行うことに よってその改修効果を検討した ${ }^{9}$. 以降では, この河道改 修試案を原型として歪模型実験を行った.

\section{（1）模型実験条件と実験方法}

模型水路は, 忠別川の河道改修試案を水平縮尺 $1 / B_{r}$ =1/600 にした複断面水路(図一1)で, 対象区間は KP6.2 $\mathrm{KP} 12.4$ である. 上流側の $800 \mathrm{~m}$ (KP11.6 KP12.4) を助走 区間とした. 下流端には水位調整も兼ねた可動式の砂止 めを，KP9.4のところには木製の取水堰模型を設置した. 模型水路全体は木製で堤外側を塗装仕上げにした.

模型実験では図-2 に示す 2 種類の河床材料(砂と火山 礫)が使われた. 砂と火山礫の平均粒径 $d_{m}$ 及び比重 (表乾 比重)はそれぞれ表-2のとおりである.

河床材料が火山礫の場合の実験条件は図ー3 の手順で 次のように決定した. 原型の河床材料の平均粒径は $d_{p}=71 \mathrm{~mm}$, 平均河床勾配は $I_{p}=1 / 138$ であり, 式(27)より 歪比 $n=1.7$, 歪比 $n\left(=B_{r} Y_{r}\right.$, ここで, $Y_{r}$ : 鈶直縮尺比 $)$ から 模型水路勾配 $I_{m}=1 / 81$, 鈆直縮尺 $1 / Y_{r}=1 / 353$ に決定した. したがって, 模型水路は勾配 $1 / 81$ の可傾斜ステージ上に 取り付けた.

低水路内移動床の初期河床面位置は対象区間の「計画 高水敷高－計画河床高」の平均值が $2.5 \mathrm{~m}$ であることから,
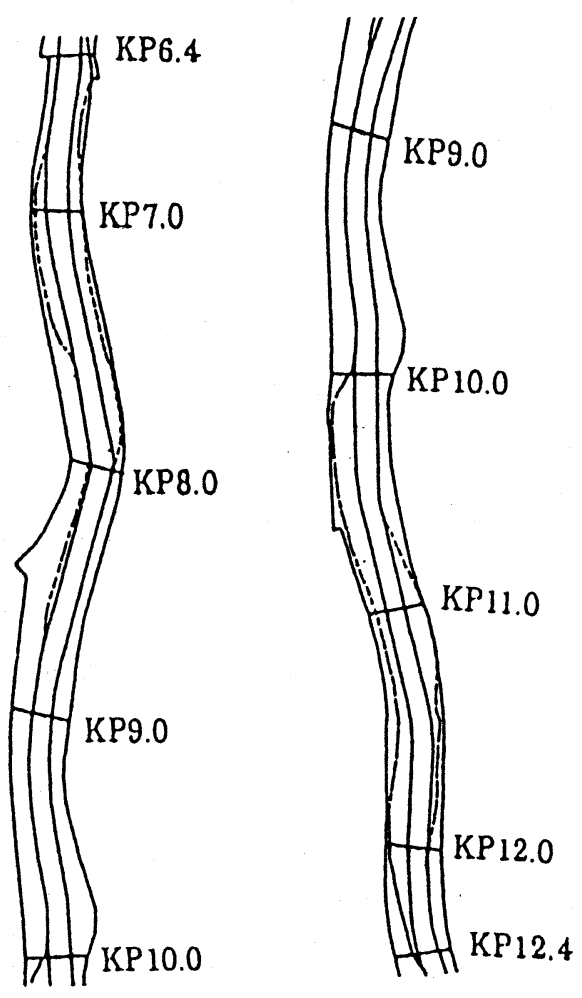

: 現況低水路

: 試案低水路

図-1 忠別川の平面図

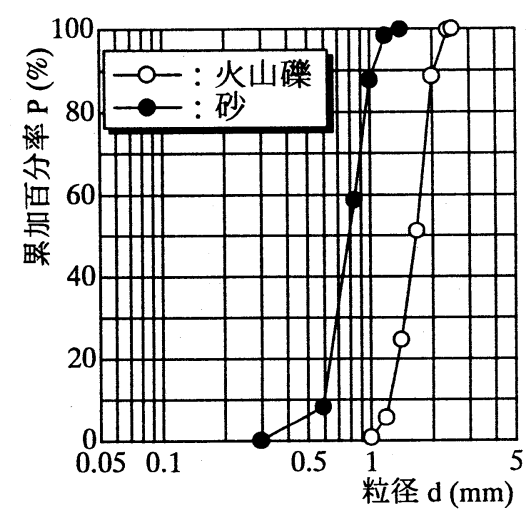

図-2 模型底質の粒度分布

表ー2 河道平面を相似にした歪模型実験条件

\begin{tabular}{|c|c|c|c|}
\hline 物理 量 & 原 型 & \multicolumn{2}{|c|}{ 平面相似にした歪 模 型 } \\
\hline 水平縮尺 & & $1 / 600$ & $1 / 600$ \\
\hline $\begin{array}{l}\text { 鈶直縮尺 } \\
\end{array}$ & - & $1 / 240$ & $1 / 353$ \\
\hline & - & 2.5 & 1.7 \\
\hline 勾 & $1 / 138$ & $1 / 55$ & $1 / 81$ \\
\hline 河床材料 & 砂喽 & 砂 & 火山礫 \\
\hline 比 & 2.65 & 2.65 & 1.34 \\
\hline 河床粒径 & $71 \mathrm{~mm}$ & $0.75 \mathrm{~mm}$ & $1.66 \mathrm{~mm}$ \\
\hline 流 & $\begin{array}{l}700\left(\mathrm{~m}^{3} / \mathrm{s}\right) \\
900\left(\mathrm{~m}^{3} / \mathrm{s}\right)\end{array}$ & $\begin{array}{l}0.426(1 / \mathrm{s}) \\
0.548(1 / \mathrm{s})\end{array}$ & $\begin{array}{l}0.146(1 / \mathrm{s}) \\
0.210(1 / \mathrm{s})\end{array}$ \\
\hline 通水時間 & 45 時間 & 17 分 38 秒 & 7 分 51 秒 \\
\hline
\end{tabular}



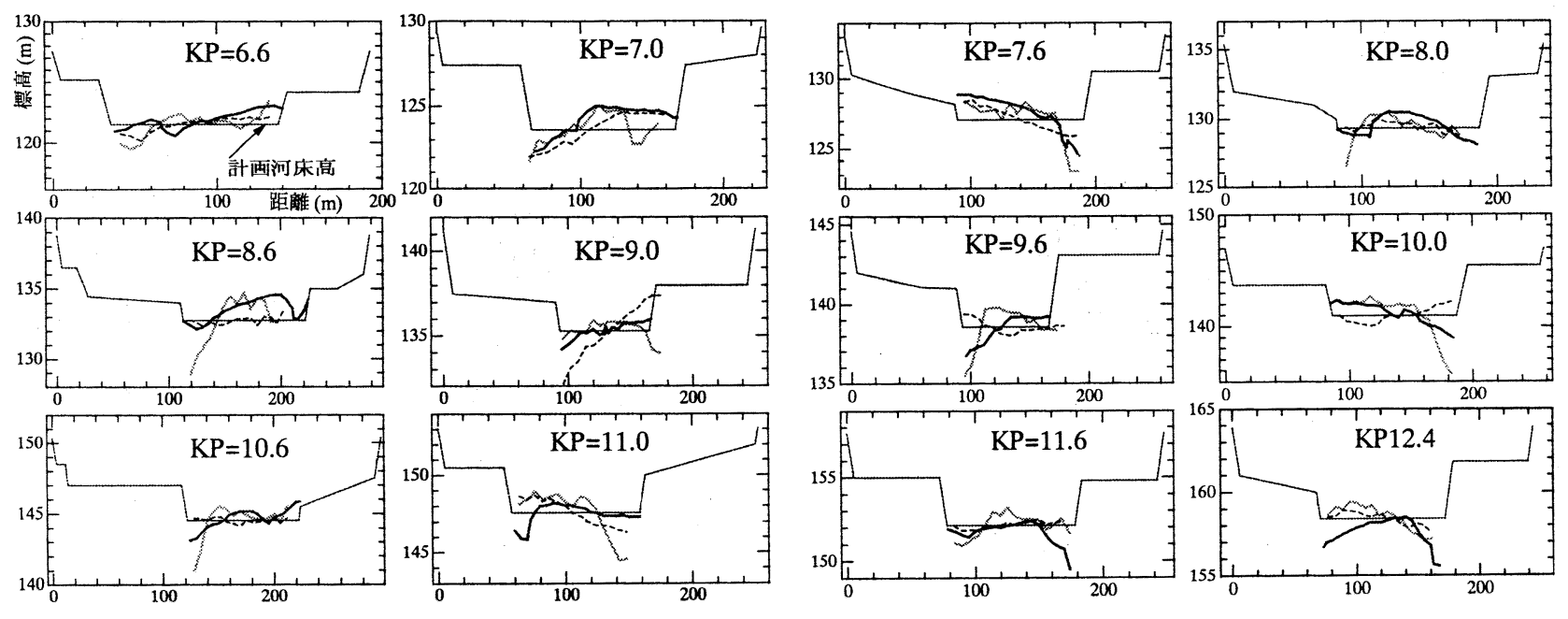

: 原型 (無歪模型)

: 歪模型 (火山磷)

- - - : 歪模型 (砂)

図-4横断河床形状の比較図

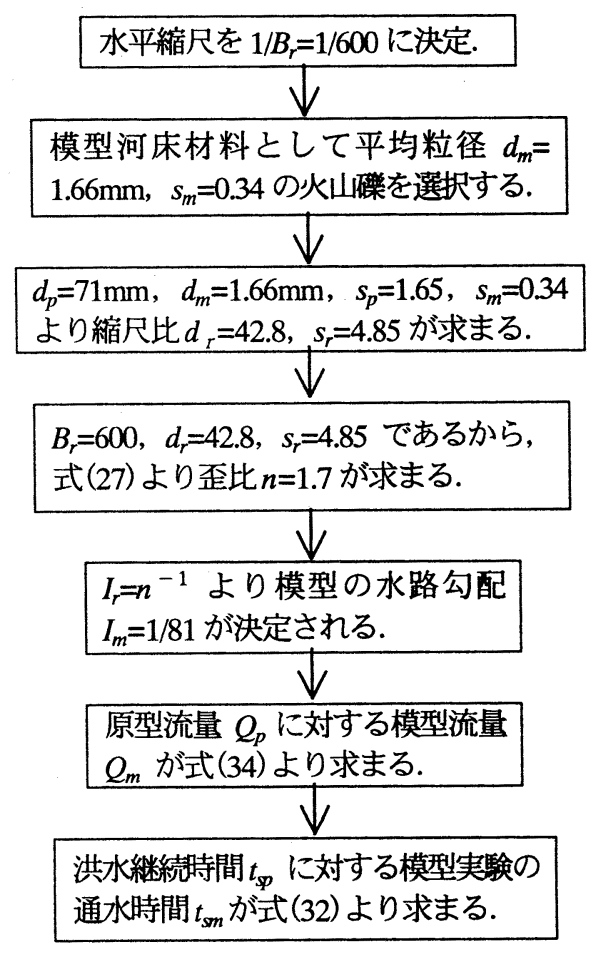

図-3 実験条件の決定

鈶直縮尺より高水敷から $7 \mathrm{~mm}$ 低い位置とした. したがっ $\tau$, 低水路満杯流量時でも模型の $h_{m} / d_{m}$ は 4 程度と小さく なるが, 山地河川の対数型抵抗則 ${ }^{10}$ である Hey 式を指数 式に近似したものは2章で取扱つたManning-Strickler抵抗 則に一致し抵抗に関する相似は成り立つと考えられる.

実験を行うに当たって, 前もって火山磁を均一に湿ら せ丹念にかき混ぜた後, コテを用いて平坦に敷き均して 初期河床面とした. また, 実験では定常状態を保持する ために水路上流端で初期河床面を維持するように手を使 つて火山磁を補給した。

実験流量は北海道開発局が行った無歪模型定常流実験

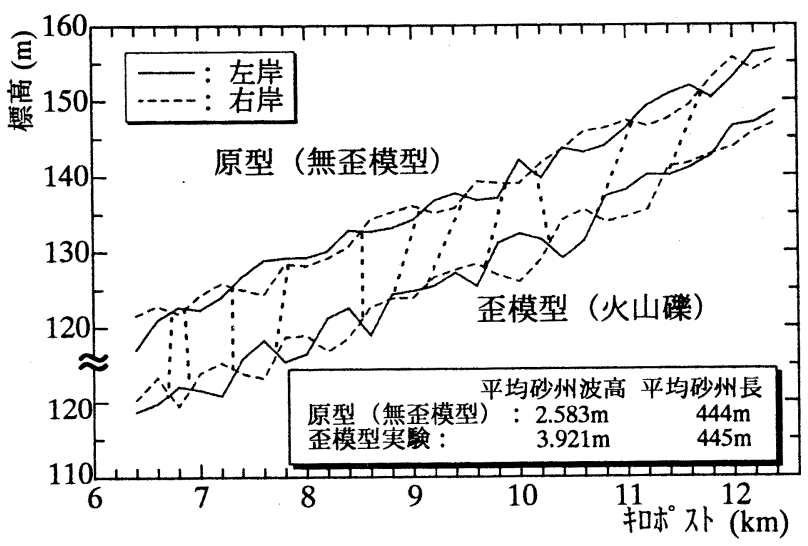

図-5 左右岸沿い河床縦断形状

（縮尺 1/50，KP6.0〜KP16.6）9)で採用した中規模洪水の $\left.Q_{p}=700,900 \mathrm{~cm}^{3} / \mathrm{s}\right)$ とし, 式(34) より模型流量 $Q_{m}=0.146$, $0.210(1 / \mathrm{s})$ を決定した (非定常流実験による本相似則の有 効性は忠別川現況河道模型で立証済みである $\left.{ }^{6)}\right)$. $Q_{p}=900\left(\mathrm{~m}^{3} / \mathrm{s}\right)$ は低水路満杯程度の流量である. また, 歪 模型流量の通水時間は, 無歪模型実験で採用した洪水継 続時間が $t_{s p}=45$ 時間であることから, 式(32)を変形した 式(36)より, $t_{s n}=7$ 分 51 秒とした. 以上の実験条件を表一 2 にまとめて示す.

$$
t_{s_{m}}=n^{-2} \cdot s_{r}^{-1} \cdot B_{r}^{-1 / 2} \cdot t_{s_{p}}
$$

河床材料が砂の場合の実験条件は, $s_{r}=1$ にして同様の 手順で決定でき，表一2に併記した.

横断河床形状の測定には自製の河床形状測定器を用い, 止水後に $200 \mathrm{~m}$ 間隔の各 KP 断面で初期河床面からの高低 差を測定した. 横断方向測定間隔は $1 \mathrm{~cm}$ である. 模型河 床の洗据深及び堆積高の原型值換算式は, 平均河床面か らの洗据深 $\xi$ 己砂州波高 $H$ が線形関係 ( $\xi=0.75 H)$ にあり, $\xi_{r}=H_{r}$ となるから, 砂州波高 $H$ の相似則 ${ }^{4)}$, 式(37）に基 
表ー3 直線水路における実験条件

\begin{tabular}{|c|c|c|}
\hline 物理量 & \multicolumn{2}{|c|}{ 直線水路丕模型 } \\
\hline 水平縮尺 & $1 / 333$ & $1 / 333$ \\
\hline 鈶直縮尺 & $1 / 177$ & $1 / 263$ \\
\hline 比 & 1.88 & 1.27 \\
\hline 勾配 & $1 / 73.4$ & $1 / 109$ \\
\hline 河床材料 & 砂 & 火山喽 \\
\hline 河床材料水中比重 & 1.65 & 0.34 \\
\hline 河床粒径 & $0.75 \mathrm{~mm}$ & $1.66 \mathrm{~mm}$ \\
\hline 流 & $\begin{array}{l}1.10(1 / \mathrm{s}) \\
1.41(\mathrm{l} / \mathrm{s})\end{array}$ & $0.529(\mathrm{l} / \mathrm{s})$ \\
\hline 通水時間 & 41 分 51 秒 & 18 分 54 秒 \\
\hline
\end{tabular}

づいて, 次の式(38) となる.

$$
\begin{gathered}
H_{r}=n^{-1} \cdot B_{r} \\
\xi_{p}=n^{-1} \cdot B_{r} \cdot \xi_{m}=Y_{r} \cdot \xi_{m}
\end{gathered}
$$

また, 模型水路の横断方向位置の原型值は $B_{r}=600$ を掛け て求められる.

\section{（2）歪模型相似則の有効性についての検証実験結果}

無歪模型実験における原型值45時間通水の定常流実験 結果と比較して移動床歪模型実験の有効性を検討するた めに, 歪模型実験も同じ通水時間で行われた. この結果, 歪模型で発生・再現された河床形態は無歪模型(移動床低 水路の最大届曲角度は KP8.0 付近の 27 度 15 分) と同様の 移動性交互砂州であった，実験結果の代表例として流量 $Q_{p}$ が $900\left(\mathrm{~m}^{3} / \mathrm{s}\right)$ 時の横断河床形状を図-4（紙数の関係で 代表例)に示す.

図ー4 は洪水流下後に止水し, 自然排水した後に各断面 について測定した横断河床形状の比較図であり, 丕模型 の河床形については平均河床高を計画河床高に一致させ て示している. 図一4 において, KP6.4〜KP8.6 の河床形 状は原型 (無歪模型) とよく一致しているが, KP8.8より 上流側の横断形状は原型と一致していない。

一般に, 移動性交互砂州は流下移動するに従って発 達·安定し, 移動速度は緩慢になる. 無歪模型実験が KP6.0 〜KP16.6 区間を対象に行われているのに対して，本歪模 型実験は KP6.4〜KP12.4 区間で行われている. したがっ て, 歪模型のKP8.8より上流側は砂州の発達域に相当し, このために原型の河床形状に一致しないと考えられる.

図ー5 は原型と火山礫を用いた歪模型の左右岸沿いの 河床縦断形状であり, 原型, 模型ともに交互砂州が発生し ていることを明膫に示している. 原型と模型の砂州の対 応関係を点線で表しているが，砂州先端の位置に違いは あるものの砂州の数はほぼ一致している. 砂を用いた模 型においてもほぼ同様な結果が得られた. このように, 移動性交互砂州発生時においても原型（無歪模型）の河 床を良好に再現可能であることが分かる.

以上の結果から, 歪模型の相似則は有効であると考え られる。

\begin{tabular}{|c|c|c|c|c|c|}
\hline 物理量 & 原型 & \multicolumn{2}{|c|}{$\begin{array}{l}\text { 平面相似にした } \\
\text { 丕模型実験 }\end{array}$} & \multicolumn{2}{|c|}{ 直線水路 } \\
\hline 河床材料 & 砂喽 & 砂 & 火山磉 & 砂 & 火山䃯 \\
\hline $\begin{array}{l}Q_{p}=700\left(\mathrm{~m}^{3} / \mathrm{s}\right) \text { 時 } \\
\text { の砂州波高 }(\mathrm{m}) \\
\quad \text { (標本数) }\end{array}$ & $\begin{array}{l}2.83 \\
(10)\end{array}$ & $\begin{array}{l}2.93 \\
(10)\end{array}$ & $\begin{array}{l}4.67 \\
(12)\end{array}$ & $\begin{array}{l}3.19 \\
(35)\end{array}$ & \\
\hline $\begin{array}{c}Q_{p}=900\left(\mathrm{~m}^{3} / \mathrm{s}\right) \text { 時 } \\
\text { の砂州波高 }(\mathrm{m}) \\
\text { (標本数) }\end{array}$ & $\begin{array}{l}2.58 \\
(12)\end{array}$ & $\begin{array}{c}2.31 \\
(9)\end{array}$ & $\begin{array}{l}3.92 \\
(12)\end{array}$ & $\begin{array}{l}2.63 \\
(49)\end{array}$ & $\begin{array}{l}6.48 \\
(35)\end{array}$ \\
\hline
\end{tabular}

表-4 再現砂州波高

\section{4. 河道湾曲を考慮した河床形相似則の考察 ${ }^{4)}$}

河道湾曲の形状は, 河道の 1 蛇行内に左右交互の方向 を持つ交互砂州 1 組（砂州 2 個）が存在する，いわゆる 蛇曲に相当する形状とし，その効果を考慮した相似則と 前章の歪模型相似則を用いて考察する.

河床洗掘深 $\eta$ は河床横断面の平均河床高からの最大深 さと定義する. $n$ の推定式は, 平均水深 $h$ で無次元化し $\tau$

$$
\frac{\eta}{h}=\frac{\eta_{H}}{h}+\frac{\eta_{b}}{h}
$$

で表される ${ }^{11)}$.ここで, $\eta_{H}$ : 河道が值線でも洗掘される 量, 即ち, 砂州に起因する洗掘深, $\eta_{b}$ : 河道の湾曲に起 因する洗掘深である.

$\eta_{b} / h$ は, 一様湾曲水路に対する理論式 ${ }^{11)}$,

$$
\frac{\eta_{b}}{h}=\frac{1}{2} N_{*}\left(\frac{\mu_{\mathrm{s}} \mu_{k} \tau_{*}}{\tau_{*_{c}}}\right)^{0.5}\left(\frac{B}{r}\right)
$$

で与えられる.ここで, $N_{*}$ : 二次流の強さを示す係数 （Rozovskii によれば $N=11 ）, \mu_{s}$ : 砂粒の静止摩擦係数 $(=1)$, $\mu_{k}$ : 砂粒の動摩擦係数 $(=0.6), r$ :曲率半径である.

式(40)によれば, $\eta_{b} / h$ の縮尺比 $\left(\eta_{b} / h\right)_{r}$ は $N_{*}, \mu_{s}, \mu_{k}$, $\tau_{{ }_{c}}$ の縮尺比を 1 としてよく, $B_{r}=r_{r}$ であり, また, $\tau_{r_{r}}=$ $\tau_{* \text { *r }}=1$ であるから,

$$
\left(\frac{\eta_{b}}{h}\right)_{r}=1
$$

となり, 河道湾曲に起因する無次元洗掘深 $\eta_{b} / h$ は, 歪の 影響を受けないことが分かる.

河道湾曲を考慮した洗掘深の相似則は，式(39) と式 （41）より，次式で表される.

$$
\left(\frac{\eta}{h}\right)_{r}=\left(\frac{\eta_{H}}{h}+\frac{\eta_{b}}{h}\right)_{r}=\frac{\left(\frac{\eta_{H}}{h}\right)_{r}+\left(\frac{\eta_{b}}{\eta_{H}}\right)_{m}}{1+\left(\frac{\eta_{b}}{\eta_{H}}\right)_{m}}
$$

直線水路における砂州波高と平均水深の相似関係は式 (28）と(37)より,

$$
\frac{H_{r}}{h_{r}}=1
$$

となり, $H_{r}=\eta_{H_{r}}$ であるから, $\left(\eta_{H} / h\right)_{r}=1$ となって 

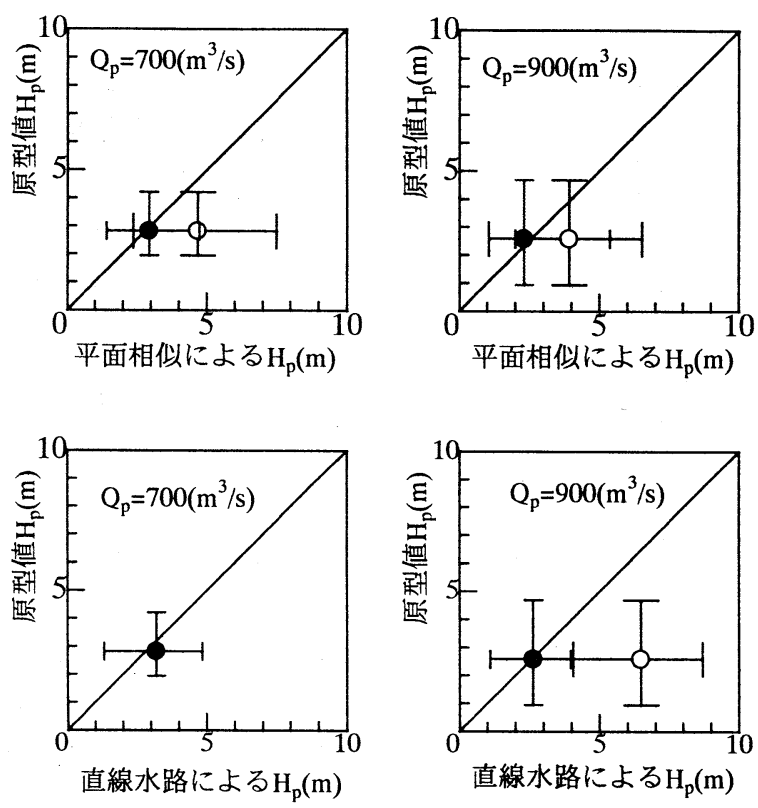

厂 $\mathbf{1}$ : 原型平均值及び範囲

ค- : 砂の場合の平均值及び範囲

○次:火山磷の場合の平均值及び範囲

図-6 砂州波高の原型值と再現砂州波高の比較

結局，式(42)は,

$$
\left(\frac{\eta}{h}\right)_{r}=1
$$

となり, $\eta / h$ も歪の影響を受けない. また, 式 (43), (44) から,

$$
H_{r}=\eta_{r}=h_{r}
$$

であり, 河道湾曲の度合に関係なく, 式(37)を適用でき ると考えられる.

試みに，前章と同に゙原型河川に対する歪模型実験を幅 $30 \mathrm{~cm}$, 長さ $13 \mathrm{~m}$ の直線水路を用いて行った. 実験条件は 表-3で, 直線水路模型においても河床形態は交互砂州で あった. その砂州波高の平均值は表-4 のとおりであり, 原型波高と比較したのが図一6である. 火山礫の場合の砂 州波高は過大に再現する. この理由は砂州波高の相似式 （37）に水中比重縮尺比 $s_{r}$ が加味されていなく, 改良の余 地がある. 砂の場合は, 原型值によく一致し, 式 (45) に関する上述のことが認められるが，原型の河道平面形 （図－1）の湾曲は小さく, 今後湾曲の大きな河道を対象 とした模型実験でさらに検証する必要がある.

\section{5. おわりに}

以上, 本研究では, まず, 一次元の流れの運動方程式 と連続式及び流砂の連続式と掃流砂量式より, 移動床歪 模型の相似則を導き，砂州形成領域区分図のパラメータ
一から得られる相似則と比較検討した. 次に, 石狩川水 系忠別川を対象とし, 北海道開発局が低水路河道改修試 案 (幅 100m) に基づいて行った縮尺 1/50 の無歪模型実験 に対し, 2 種類の河床材料 (砂と火山喽) を用いた歪模型 実験を行って歪模型相似則の有效性と共に, 河道湾曲を 考慮した砂州河床の相似性について検討した. その結果 をまとめると, 以下のようである.

1)一次元の流れの運動方程式と連続式及び流砂の連続式 と掃流砂量式より歪模型相似則を導くことによって, 領域区分図に基づく相似則について理論的に補完し た.

2) 模型の河床材料か砂, 火山喽にかかわらず, 歪模型実験 で原型（無歪模型）の移動性交互砂州河床形状を再現 できる(模型水路の制約から上流側の発達過程にある 砂州を除く)ことが明らかになり, 移動床歪模型実験の 有用性及び本研究で用いた歪模型相似則の有効性を確 認できた。

3) 河道湾曲の度合があまり大きくない蛇曲程度の砂州河 床河川に対しては，本相似則を用いた直線水路模型実 験で砂州波高, 即ち, 洗掘深を推定できる可能性があ ることを示した.

\section{参考文献}

1) Einstein, H. A. and Chien N.: Similarity of Distorted River Models with Movable Beds, Trans. ASCE, Vol.121, pp. 440-457, 1956.

2) Yalin, M. S.: Theory of Hydraulic Models, Macmillan, 266p, 1971.

3) 内島邦秀- 早川博: 交互砂州河床河川の移動床歪模型の相似 則に関する研究，土木学会論文集，No.479/II-25, pp.71-79, 1993.11.

4）内島邦秀 : 中規模河床形態の相似則，1995 年度 (第31 回) 水 工学に関する夏期研究会講義集, A4, pp.1-16, 1995.

5）内島邦秀·井出康郎 · 加治昌秀 - 宇山幹紀 - 早川博 : 忠別川 の移動床丕模型実験, 土木学会北海道支部論文報告集, 第 51 号 (B), pp.178-183, 1995.

6）内島邦秀・高木厚 - 井出康郎 - 加治昌秀 - 早川博 : 移動床歪 模型実験による洪水時河床変動の検討, 水工学論文集, 第 41 巻, pp.1003-1010, 1997.

7）鮏川登: 実験水路における交互砂州(砂れき堆)の形成条件, 土木学会論文報告集, 第207 号, pp.47-50, 1972.

8）須賀克三: 水理模型実験, 山海堂, 1990.

9）北海道開発局開発土木研究所 - (財) 河川環境管理財団 : 平 成 7 年度大型水路水理実験検討業務の内急流河川水理模型 実験報告書, 1995 .

10）長谷川和義 : 山地河川の形態と流れ，1988 年度（第24回） 水工学に関する夏期研修会講義集, A8, pp.1-22,1988.

11）渡遑康玄·長谷川和義·北條鿆次: 河川デー夕による河床洗挏 の水理要因に関する検討, 水工学論文集, 第 34 巻, pp.313-318,1990.

(2000.10.2 受付) 